\title{
Technical Difficulties Faced in Restoring Pre Handled Machinaries Used for Large Scale Production
}

\author{
S. Jeni Theresa, S. Janifar Vinnarasi, R. Vasuki,
}

\begin{abstract}
The paper assesses the determinants of intentional $P E$ and VC monetary experts' ownership in the post-IPO period. I show that these monetary masters hold offers to direct potential managerial seizure of outside financial specialists, yet their support fondness depends basically on the focal characteristics of IPO, PE and VC firms, adventure, and divestment power of different pre-IPO speculators. I find that the financial benefactors' required holding is in a general sense greater in US than in UK IPOs. The assessment of the affiliate's trade execution, considering the timetable time approach, reveals strong negative ordinary month to month irregular returns for game plan of upheld IPOs over various holding periods, anyway the association between PE/VC purposeful ownership and the since a long time prior run execution is curved, prescribing that solitary colossal property make regard.
\end{abstract}

Key words: of IPO, PE

\section{INTRODUCTION}

Private value (PE) and funding (VC) financial specialists assume an indispensable job in numerous nations. These money related backers give capital, complete exceptional rebuilding, improve administration, adjust the interests of supervisors and investors, give confirmation, and improve advancement and execution.

The capital gave by $\mathrm{PE}$ and $\mathrm{VC}$ houses addresses an alternative 3 kind of financing open to firms. Various countries around the world plan to empower new interests in order to deliver extended money related achievement and lift work creation (Eberhart et al, 2014). In a continuous report, Chemmanur and Fulghieri (2014) include the creating centrality of cash related center individuals in developing ambitious firms in the general setting. They battle that mainly two parts have incited an extended unquestionable nature of creative record. In any case, globalization empowered cross periphery adventures, especially in creating nations. Furthermore, these nations have set up their own one of a kind VC industry. Second, mechanical progression which realized improved correspondence across over colossal divisions and lower related costs. These two theorists give, regardless, financing to different sorts of firms. Venture capital (VC) and private worth (PE) firms are

Revised Manuscript Received on December 11, 2019

S.Jeni Theresa Assistant Professor, Department Of Science \& Humanities, Bharath Institution Of Higher Education And Research. TamilNadu,India.Email: littleflower1812@gmail.com

S.JanifarVinnarasi, Assistant Professor, Department Of Science \& Humanities, Bharath Institution Of Higher Education And Research TamilNadu,India.Email: mjjaa24@gmail.com

R.Vasuki,Assistant Professor, Department Of Science \& Humanities, Bharath Institution Of Higher Education And Research TamilNadu,India.Email: vasukiteacher@gmail.com known to place assets into associations in order to coordinate a concentrated revamping, give assertion, checking and regard including works out. Right when portfolio associations are under private ownership, $\mathrm{PE}$ and $\mathrm{VC}$ money related authorities interface pay to execution, decentralize fundamental administration, similarly as change the course of action and handiness of the top administrative staff (Baker and Wruck, 1989; Baker and Gompers, 2003; Hochberg, 2003; Acharya et al, 2009). They by then will all in all get them to the money related trade the sort of starting open commitments (IPOs) to comprehend their benefits, as this system is the most enjoyed (Giot and Schwienbacher, 2007), and profitable leave course (Brau et al, 2003) I expect VC and $\mathrm{PE}$ theorists to hold esteem property in the post-IPO period in firms which are presumably going to make higher since a long time prior run returns, for at any rate two reasons. In the first place, given that these benefits are capable monetary experts who require a high pace of return, their property could be viewedwithin their general hypothesis framework. Subsequently, they are presumably going to keep holding stakes in IPOs with incredible improvement openings. Second, since they had contribution with placing assets into the pre-IPO period, they are presumably going to know better the firm and to be practical screens. placing assets into the pre-IPO period, they are most likely going to know better the firm and to be successful screens. Notwithstanding the different characteristics of PE-and VC-supported associations, the two sorts of monetary masters convey associations to the protections trade, and their incorporation with the as of late refered to firm, through generally their potential watching work, is most likely going to impact the bounty of the new financial specialists. Also, there are a couple of various reasons principal the motivation for an increasingly significant assessment of the PE-and VC-upheld IPOs. To begin with, such IPOs have for since a long time prior involved one of the noteworthy techniques for setting off to the money related trade.[1]-[5] For example,

\section{Literature REVIEW:}

Brav and Gompers (2003) propose three clarifications for the presence of lockup understandings: a sign of firm quality, a responsibility gadget, and a component to separate extra remuneration from the giving firm. A few past investigations look at the flagging part of lockups.

Gompers and Lerner (1998) analyze share disseminations made to LPs post-flotation, 16 and find that, by and large, VC firms make most of offer conveyances twenty months after the IPO date. 
Courteau (1995) analyzes another part of lockup understanding, for example its length, and contends that organizations signal their predominant quality by methods for longer lockup term.

Leland and Pyle (1977) consider possession maintenance by insiders, and contend that when an insider sells a critical level of offers at the IPO it flag the association's overvaluation. Conversely, insiders who hold shares for more and persevere through the expense of staying undiversified sign unrivaled nature of the organization. [6]-[10]

\section{A. Approach:}

Inside and out writing audit and accessible auxiliary information from different sources has been utilized to build up this paper.

\section{B. Information Sources and Sample:}

The example utilized in this examination incorporates all non-budgetary PE-and VC-upheld IPOs drifted in the US and UK showcases somewhere in the range of 1997 and 2010. I use LSE for UK and SDC database for US to gather IPO names and dates of confirmation. I prohibit money related IPOs due to their particular attributes, especially their capital structure.I recognize monetarily supported IPOs from a few sources. I utilize additionally quarterly proprietorship information to affirm whether financial specialists determined in the 'significant investors' segment of IPO outlines are people or institutional speculators. [11]-[15]

PE and VC Syndicate Size:I utilize various PE/VC store and syndicate attributes as intermediary factors in this paper. It is basic for PE and VC putting to happen in a syndicate. In this paper, I use syndicate size as an intermediary variable for firms' ethical danger and hazard.

\section{RESULTS \& DISCUSSION}

The changes in the quantity of IPOs look like the patterns reported by Ritter et al (2013) who contend this mirrors the market timing contemplations (Ritter, 2003). Over the example time frame, VC-sponsored IPOs experienced two observable tops: the dotcom air pocket of 1999 in the US and 2000 in the UK, with a development rate in VC IPOs arriving at $272 \%$ and $625 \%$, individually. The pinnacles of action are trailed by not many IPOs because of 2000 accident. In general, rather than UK, the US IPO market had a speedier 'recuperation' and budgetary backers kept on bringing portfolio organizations to the financial exchange to acknowledge returns somewhere in the range of 2008 and 2010. In the UK, about half of monetarily supported IPOs in any industry are sponsored by financial speculators. [16]-[20]

Notwithstanding, VC speculators put all the more intensely in cutting edge, social insurance, and media transmission ventures in the US. Steady with PE and VC speculation criteria, PE firms' ventures are dominatingly packed in vitality, non-durables and assembling parts in the US.

\section{A. Targets:}

1. To locate a critical positive connection between firm worth and part of offers held by institutional speculators.

\section{CONCLUSION}

Private value and funding speculators acknowledge returns by bringing their portfolio organizations to the securities exchange (or some other divestment course) following quite a while of broad rebuilding, supporting, observing and esteem creation. Past studies have reported PE and VC financial specialists' proceeded with inclusion in organizations post-buoyancy as far as possession and portrayal on the top managerial staff (Cao, 2011; Krishnan et al, 2011). This paper sheds lights on the principal question of what decides PE/VC necessary and willful proprietorship maintenance, and its impact on the since quite a while ago run execution of UK and US upheld IPOs. The degree of leave post the lockup termination date is specifically compelling, since it is the principal open door for PE and VC syndicates to deliberately choose their divestment system. I locate that great working presentation empowers PE and VCs to exit completely US firms at the lockup lapse[21]-[25]

\section{REFERENCES}

1. Vasanthi, S. \& Rabiyathul Basariya, S. 2019, "Influence of value analysis and cross training in industry", International Journal of Engineering and Advanced Technology, vol. 8, no. 6, pp. 1810-1811.

2. Velvizhi, R., Sri Gowtham, S. \& Jeya Priya, D. 2019, "Examination of early feedbacks for effective product retailing on E-commerce websites", International Journal of Engineering and Advanced Technology, vol. 8, no. 6 Special Issue 2, pp. 703-706.

3. Anuradha, C., Pothumani, S. \& Kavitha, R. 2019, "A novel method towards E-commerce", International Journal of Engineering and Advanced Technology, vol. 8, no. 6 Special Issue 2, pp. 535-538.

4. Thomas, J. \& Rabiyathul Basariya, S. 2019, "A study on the issues of financial ratio analysis", Indian Journal of Public Health Research and Development, vol. 10, no. 3, pp. 1079-1081.

5. Ramachandran, S. \& Rabiyathul Basariya, S. 2019, "Online marketing study on customer satisfaction and relationship", Indian Journal of Public Health Research and Development, vol. 10, no. 3, pp. 1072-1078.

6. Priya, R., Vinothini, G. \& Cor Jesu, C.D. 2019, "The mentor-protégé relationship for professional growth", Journal of Advanced Research in Dynamical and Control Systems, vol. 11, no. 9 Special Issue, pp. 1110-1119.

7. Jannifer Rani, N., Bina Pani, S. \& Nimisha, N.S. 2019, "A study on money back polices available in LIC", Journal of Advanced Research in Dynamical and Control Systems, vol. 11, no. 9 Special Issue, pp. 833-839.

8. Saillaja, V., Jhansi Rani, K. \& Catherine, R. 2019, "Global marketing management planning and organization", Journal of Advanced Research in Dynamical and Control Systems, vol. 11, no. 9 Special Issue, pp. 489-493.

9. Saillaja, V., Jhansi Rani, K. \& Catherine, R. 2019, "The new phase of marketing information system", Journal of Advanced Research in Dynamical and Control Systems, vol. 11, no. 9 Special Issue, pp. 482-488.

10. Thoufiqulla \& Raju, D.V. 2019, "Perception of indian investor towards investment in mutual funds with special reference to mip funds", Journal of Advanced Research in Dynamical and Control Systems, vol. 11, no. 5, pp. 177-183. 
11. Jasmine, K.R.M. \& Basariya, S.R. 2018, "A study on the customers benefits on mutual funds", International Journal of Civil Engineering and Technology, vol. 9, no. 4, pp. 45-48.

12. Vasanthi, S. \& Basariya, S.R. 2019, "Pros and cons of on the job training versus off the job training", International Journal of Scientific and Technology Research, vol. 8, no. 10, pp. 671-674.

13. Pavithra, J. \& Ganesan, M. 2016, "A study on awareness and impact of micro-financial schemes", International Journal of Applied Business and Economic Research, vol. 14, no. 8, pp. 5449-5460.

14. Pavithra, J., Dilli Babu, P. \& Ambuli, T.V. 2014, "A study on budgetary control at Maruti Service Masters, Chennai", International Journal of Applied Business and Economic Research, vol. 12, no. 2, pp. 151-161.

15. Gunaraja, T.M. \& Venkatrama Raju, D. 2018, "Determining factors of organisational climate with reference to leadership styles", International Journal of Mechanical Engineering and Technology, vol. 9, no. 9, pp. 1327-1332.

16. Gunaraja, T.M. \& Venkatrama Raju, D. 2018, "The role of job satisfaction and training of employees in determining organisational climate of a selected industry", International Journal of Civil Engineering and Technology, vol. 9, no. 8, pp. 1266-1269.

17. Aarathy, T.S. \& Raju, D.V. 2018, "Performance appraisal and its effects on employees with respect to it sector in Chennai city", International Journal of Civil Engineering and Technology, vol. 9, no. 6, pp. $1535-1538$.

18. Aarathy, T.S. \& Raju, D.V. 2018, "Employee perception towards performance appraisal system in IT sector", International Journal of Mechanical Engineering and Technology, vol. 9, no. 5, pp. 131-135.

19. Porselvi, W., Jublee, D. \& Sivanesan, G. 2018, "A study on factors influencing adoption of technology and innovation in banking industry, tamilnadu, India", International Journal of Mechanical Engineering and Technology, vol. 9, no. 5, pp. 789-800.

20. Akessa, G.M. and Dhufera, A.G., 2015. Factors That Influences Students Academic Performance: A Case of Rift Valley University, Jimma, Ethiopia. Journal of Education and Practice, 6(22), pp.55-63.

21. Miller, G. and Shih, C.C., 1999. A faculty assessment of the academic rigor of on-and off-campus courses in agriculture. Journal of Agricultural Education, 40, pp.57-65.

22. Tsinidou, M., Gerogiannis, V. and Fitsilis, P., 2010. Evaluation of the factors that determine quality in higher education: an empirical study. Quality Assurance in education, 18(3), pp.227-244.

23. Farooq, M.S., Chaudhry, A.H., Shafiq, M. and Berhanu, G., 2011. Factors affecting students' quality of academic performance: a case of secondary school level. Journal of quality and technology management, 7(2), pp.1-14

24. Fitsilis, P., Gerogiannis, V. and Anthopoulos, L., 2014. Ontologies for software project management: a review. Journal of Software Engineering and Applications, 7(13), p.1096.

25. Adams, J.D. and Jaffe, A.B., 1996. Bounding the effects of R\&D: an investigation using matched establishment-firm data(No. w5544). National bureau of economic research.

\section{AUTHORS PROFILE}

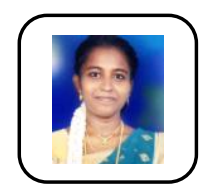

S.Jeni Theresa Assistant Professor, Department Of Science \& Humanities, Bharath, Institution Of Higher Education And Research. TamilNadu,India

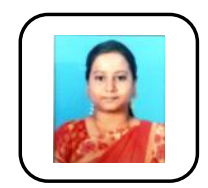

S.JanifarVinnarasi, Assistant Professor, Department Of Science \& Humanities, Bharath Institution Of Higher Education And Research TamilNadu,India

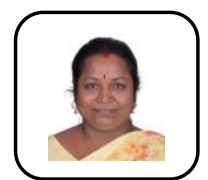

R.Vasuki,Assistant Professor, Department Of Science \& Humanities, Bharath Institution Of Higher Education And Research TamilNadu,India 